\title{
RELATIONSHIP BETWEEN ATTACHMENT STYLES AND DIMENSIONS OF THE RELIGIOUS CONVERSION PROCESS
}

\author{
Peter HALAMA ${ }^{1}$, Marta GAŠPARÍKOVÁ ${ }^{2}$, Matej $\mathrm{SABO}^{2}$ \\ ${ }^{1}$ Institute of Experimental Psychology, Slovak Academy of Sciences \\ Dúbravská cesta 9, 84104 Bratislava, Slovak Republic \\ E-mail: peter.halama@savba.sk \\ ${ }^{2}$ Department of Psychology, Faculty of Philosophy, University of Trnava \\ Hornopotočná 23, 91843 Trnava, Slovak Republic
}

\begin{abstract}
The study is based on the assumption that the attachment system is closely related to religiosity and religious behavior. Previous research showed that a type of attachment was related to religious conversion. Insecure attachment was related to sudden and emotional conversion and secure attachment was related to gradual adoption of caregiver's religion. The present research focused in more detail on the relationship between attachment styles and the religious conversion process. 101 Christian converts filled out the Religious Conversion Process Questionnaire measuring different aspects of how conversion came about, and two attachment questionnaires: Attachment History Paragraphs for measuring attachment towards parents and Relationship Questionnaire measuring attachment in the current relationships. Pearson correlation analysis of the relations between conversion dimensions and attachment styles showed that secure attachment towards parents was related to the presence of some religiosity education before conversion and parents being a positive factor in the conversion. On the other hand, insecure attachment toward parents (especially toward the father) correlated with experiencing religious conversion as a more sudden, emotionally driven process accompanied by mystical experiences. These results gave support to both, compensation and socialized correspondence hypotheses as described in attachment and religion research and theory.
\end{abstract}

Key words: attachment styles, religion, religious conversion

Many psychological theories have been used to analyze psychological aspects of religious behavior and feeling. One of the most influential theories, which were applied to religious phenomena, is the attachment theory. Attachment theory was originally developed by Bowlby $(1969,1973)$ and his followers (Ainsworth et al., 1978; Main, Cassidy, 1988) and it emphasized the importance of mother-child relationship quality in

The study was partially supported by Grant Agency VEGA No. 1/0250/12. psychological health. It was used as a clinical-developmental approach for the analysis of child behavior, focusing on the quality of the attachment figures as an influence on psychological functioning of a child. Bowlby $(1969,1973)$ suggested that the need to establish attachment with a primary caregiver is an important evolutional need, which ensures an adequate adaption to environment. A child interacts with the primary caregiver and produces attachment behavior, which includes searching for proximity especially during distress. The results of these interac-

DOI: $10.21909 /$ sp.2013.03.635 
tions are internal working models, which are cognitive representations of the child's experience with primary caregivers. As quality of these interactions can be different, internal working models also display individual differences, which are known as attachment styles. Ainsworth et al. (1978) distinguish a secure attachment style (representation of accessible and responsive figure) and two types of insecure attachment styles: ambivalent attachment (figure is only sometimes accessible and responsive) and avoidant attachment (figure is not accessible and not responsive). Lately, Main and Solomon (1996) added a fourth category: disorganized attachment, which is represented by chaotic and awkward behavior of the child, and it is classified when none of the previous styles can be identified.

Development in the area of attachment theory brought broadening of the scope of the attachment theory and it started to be used as an approach for analyzing adult social behavior and mental health (Mikulincer, Shaver, 2007). It was shown that there are similarities between child attachment behavior and behavior of the adult person in close relationships. Adult person also seeks proximity of the close person especially in time of discomfort and derives feelings of safety from his or her presence (Feeny, 1999). There appeared several models of adult attachment styles. Hazan and Shaver (1990) developed the three-category model of the adult attachment based on Ainsworth's previous work on child attachment. This classification included secure, anxious ambivalent and avoidant attachment. Secure attachment describes a person who feels comfortable in relationships and it is relatively easy for him or her to get close to other people. Anxious ambivalent person perceives other people as reluctant to be in the relationship with him or her and worry about other's love. Avoidant person feels discomfort when they are close to others and they try to avoid intimacy and closeness. Bartholomew and Horowitz (1991) developed a four-category model based on two dimensions: positive vs. negative model of self and positive vs. negative model of others. Positive model of self and others is characteristic for secure attachment. Persons with preoccupied attachment have positive model of others but negative model of self. On the contrary, negative model of others and positive model of self form fearfulavoidant attachment. Finally, the combination of negative model of self and others is typical for dismissive attachment. The research on adult attachment has brought many results, especially in the area of close relationships. Cobb et al. (2001) found that secure attachment correlates with marital satisfaction, both perceived in him or herself or in the partner. Pietromonaco et al. (2004) reviewed more than twenty studies on attachment and couple conflicts. They found that persons with secure attachment tend to react more constructively during the couple's conflicts, which leads to deeper intimacy and higher satisfaction.

Many areas accepted the attachment theory as an explanatory framework for the researched phenomena. Psychology of religion was one of them, especially due to similarities between attachment to parents and attachment to God. One of the first research studies that brought together attachment and religiosity was that of Kirkpatrick and Shaver (1990). The authors formulated two hypotheses related to attachment and religiosity. Compensation hypothesis assumes that individuals who have experienced insecure childhood attachment relationships with 
their primary attachment figures are in greater need to establish compensatory attachment relationships with God to regulate emotional distress. On the other hand, correspondence hypothesis suggests that individuals who have experienced secure childhood attachments have established the foundations upon which a corresponding relationship with God could be built. In their longitudinal research, the authors found that persons with insecure attachment had a higher probability to experience sudden religious change or religious experience, which supported the compensation hypothesis. These findings were confirmed also in later studies (Kirkpatrick, 1997, 1998). Further research on attachment and religiosity focused on the different religious dimensions and their relation to attachment styles. Adamovová and Halama (2009) supported the compensation hypothesis as they found correlation between disorganized attachment toward the mother and religious fundamentalism, but only in women. On the other hand, religious fundamentalism in men showed positive correlation with secure attachment. Many studies focused on attachment to God. Kirkpatrick (2005) argued that God can function as an attachment figure, because people seek safety and proximity in God, especially in time of stress. The research showed that there are weak but positive correlations between parental and God attachment, somewhat higher for the father (McDonald et al., 2005; Limke, Mayfield, 2011). Secure attachment to God predicts lower perceived stress and higher existential well-being; insecure attachment to God predicts higher level of negative attachment (Reiner et al., 2010; Miner, 2009; Mendonca et al., 2007).

Religious conversion belongs to the religious phenomena, which were frequently analyzed through the attachment theory. The relationship between parents' behavior and some aspects of conversion was known from non-attachment studies. Ullman (1982, 1989) found that nearly 80 percent of converts in her sample spoke about a problematic relationship with their father, compared to 23 percent in the non-convert group. Most of the converts remembered their father as missing, passive, non-present, actively avoiding, etc. Buchbinder et al. (1997) also confirmed this finding, as they found 61 percent of converts speaking about a problematic relationship with the father. Both studies found a similar effect for the mother, but this was not as strong as for the father. Murken a Namini (2007) found that converts to new religious movements (NRM) had higher numbers of problems in their families (divorce, death of parent, etc.). Relationships between attachment and conversion are supported by series of studies by Kirkpatrick (Kirkpatrick, Shaver, 1990; Kirkpatrick, 1997, 1998), which were already mentioned above. All these studies confirmed that positive religious change (in the sense of developing more intensive relationship with God), was predicted by insecure attachment. Buxant et al. (2007) studied converts to NRM and they found that members of NRM had a higher number of insecure attachments in comparison to normal population. They see their results as supporting the compensation hypothesis, which means that persons with insecure attachment find relief and safety in religion. Granqvist (1998) also found that persons with insecure attachment had higher probability of sudden religious change, but this relationship was moderated by the parent's religiosity. In the case of high parent religiosity, persons with secure attachment had higher probability to be religious 
than persons with insecure attachment. Granqvist perceived this finding as a support for both compensation and correspondence hypotheses and he formulated the socialized correspondence hypothesis (Granqvist, 2003), which was a broadening of correspondence hypothesis. He supposed that individuals who have experienced secure childhood attachments have established the foundations upon which a corresponding relationship with God could be built and are successfully socialized to adopt the attachment figure's religious or nonreligious standards. In 2004, Granqvist and Kirkpatrick (2004) created a meta-analysis focusing on attachment and religious conversion, aiming to identify the support for compensation and socialized hypotheses. They found confirmation for both of the hypotheses. Sudden conversions were associated with insecure attachment rather than secure attachment histories, and non-sudden conversions and gradual religious changes were associated with a secure attachment history. Support for both hypotheses was also found by Schnitker et al. (2012), who studied conversion narratives of adolescents who attended a religious camp.

\section{Goal of the Study}

In our study, we focused on the relationship between attachment styles and the conversion process in more detail. Previous studies did not study the conversion process in a detailed way, and they took conversion as a simple affair (e.g., emotional vs. rational, sudden vs. long-termed). This study aims to identify the relationship between attachment styles and different aspects of the religious conversion process. We suppose that both, people with secure and insecure attachment, experience religious conversion but they process it differently. On the base of previous research, especially by Granqvist and Kirkpatrick (2004), we suppose that secure attachment will correlate with positive social and emotional characteristics of conversion, and insecure attachment with negative emotional characteristics (crisis and stormy emotion during conversion).

\section{METHOD}

\section{Sample}

The sample in this study consisted of 101 religious persons who defined themselves as converts. They were recruited at religious meetings, through different religious communities and subsequently by the snowball method. All participants belonged to the Catholic Church and they participated anonymously in the study. 38 of them were males and 63 females. Their age varied from 19 to 70 years, with mean of 32.65 years. Average age of conversion was 21.35 years (ranging from 15 to 47 years).

\section{Measures}

For measuring the conversion process, we used the Religious Conversion Process Questionnaire (RCPQ, Halama, 2005) which measures different aspects of how conversion came about. It comprises 50 items related to various aspects of conversion (antecedents, experiences during conversion, consequences, etc.). The convert is asked to answer the items on a 4-point scale. The questionnaire is not a standard scale, rather it is a flexible measure tool, which is open to reanalysis of its dimensions in different samples. The dimensions of the question- 
naire used in this research were identified through hierarchical cluster analysis in a previous research (Halama, 2005) and are shown in Table 1. The table shows names, numbers of items, short descriptions and item examples for each of the 14 dimensions.

Table 1. Dimensions of the Religious Conversion Process Questionnaire

\begin{tabular}{|c|c|c|c|}
\hline $\begin{array}{l}\text { Dimension of } \\
\text { conversion process }\end{array}$ & $\begin{array}{l}\text { Number } \\
\text { of items }\end{array}$ & Definition & Item(s) example \\
\hline Positive emotions & 3 & $\begin{array}{l}\text { experiencing positive } \\
\text { emotions during } \\
\text { conversion }\end{array}$ & $\begin{array}{l}\text { During my conversion, I } \\
\text { intensely experienced } \\
\text { God's love and presence }\end{array}$ \\
\hline Social influence & 5 & $\begin{array}{l}\text { influence of other } \\
\text { people on the } \\
\text { conversion process }\end{array}$ & $\begin{array}{l}\text { My conversion was } \\
\text { significantly influenced } \\
\text { by other people who } \\
\text { mediated faith to me }\end{array}$ \\
\hline Relief & 6 & $\begin{array}{l}\text { solving problems, } \\
\text { alleviation, change of } \\
\text { negative emotions and } \\
\text { self-esteem }\end{array}$ & $\begin{array}{l}\text { My conversion helped me } \\
\text { to solve many problems } \\
\text { in my life }\end{array}$ \\
\hline Meaning-searching & 3 & $\begin{array}{l}\text { conversion as an } \\
\text { outcome of searching } \\
\text { for meaning and new } \\
\text { worldview }\end{array}$ & $\begin{array}{l}\text { Before my conversion I } \\
\text { asked myself many } \\
\text { questions about my life } \\
\text { and its meaning }\end{array}$ \\
\hline Feelings of sin & 3 & $\begin{array}{l}\text { having formal faith } \\
\text { before conversion, } \\
\text { feelings of sin before } \\
\text { conversion }\end{array}$ & $\begin{array}{l}\text { My conversion was } \\
\text { preceded by intensive } \\
\text { feeling of my sinfulness. } \\
\text { My faith before } \\
\text { conversion was only } \\
\text { formal }\end{array}$ \\
\hline Parents positive & 2 & $\begin{array}{l}\text { parents as positive } \\
\text { factor in religious } \\
\text { conversion, } \\
\text { correspondence with } \\
\text { new faith }\end{array}$ & $\begin{array}{l}\text { My good relationship } \\
\text { with my parents helped } \\
\text { me to see God as loving } \\
\text { and kind during my } \\
\text { conversion. }\end{array}$ \\
\hline Religious education & 2 & $\begin{array}{l}\text { influence of previous } \\
\text { religious education on } \\
\text { conversion }\end{array}$ & $\begin{array}{l}\text { It was helpful for my } \\
\text { conversion that I knew } \\
\text { much about faith from my } \\
\text { family, school etc. }\end{array}$ \\
\hline $\begin{array}{l}\text { Long-termed } \\
\text { conversion }\end{array}$ & 5 & $\begin{array}{l}\text { long-termed conversion } \\
\text { occurred as a more } \\
\text { placid and calm process }\end{array}$ & $\begin{array}{l}\text { My conversion was long- } \\
\text { termed and gradual, My } \\
\text { conversion was quiet and } \\
\text { calm }\end{array}$ \\
\hline
\end{tabular}

Table continues 
Table 1 (continued)

\begin{tabular}{|c|c|c|c|}
\hline $\begin{array}{l}\text { Dimension of } \\
\text { conversion process }\end{array}$ & $\begin{array}{l}\text { Number } \\
\text { of items }\end{array}$ & Definition & Item(s) example \\
\hline $\begin{array}{l}\text { Parents } \\
\text { compensation }\end{array}$ & 2 & $\begin{array}{l}\text { conversion as a } \\
\text { compensation for } \\
\text { insufficient parents and } \\
\text { reparation of negative } \\
\text { family background }\end{array}$ & $\begin{array}{l}\text { My new relationship with } \\
\text { God replaced the } \\
\text { unsatisfactory love of my } \\
\text { parents }\end{array}$ \\
\hline Internal process & 5 & $\begin{array}{l}\text { conversion as internal } \\
\text { and cognitive process } \\
\text { without influence of } \\
\text { other people }\end{array}$ & $\begin{array}{l}\text { My conversion was my } \\
\text { internal process not } \\
\text { influenced by other } \\
\text { people. }\end{array}$ \\
\hline Crisis before & 2 & $\begin{array}{l}\text { negative experience or } \\
\text { crisis before conversion }\end{array}$ & $\begin{array}{l}\text { Before conversion, I } \\
\text { experienced an intensive } \\
\text { crisis in my life }\end{array}$ \\
\hline Negative emotions & 3 & $\begin{array}{l}\text { negative feelings, } \\
\text { struggles, tension or } \\
\text { fear of new demands } \\
\text { during conversion }\end{array}$ & $\begin{array}{l}\text { My conversion was } \\
\text { accompanied by } \\
\text { struggles and doubts }\end{array}$ \\
\hline No religiosity before & 3 & $\begin{array}{l}\text { no religious } \\
\text { background, contact } \\
\text { with different religions } \\
\text { before conversion }\end{array}$ & $\begin{array}{l}\text { I have never met with } \\
\text { faith before my } \\
\text { conversion }\end{array}$ \\
\hline Sudden and mystical & 4 & $\begin{array}{l}\text { sudden conversion with } \\
\text { intensive and mystical } \\
\text { experiences }\end{array}$ & $\begin{array}{l}\text { My conversion was } \\
\text { sudden and unexpected, } \\
\text { My experiences during } \\
\text { conversion can be } \\
\text { described as mystical }\end{array}$ \\
\hline
\end{tabular}

Two measures were used for the measurement of attachment. Attachment History Paragraphs (Hazan, 1990, in Granqvist, Kirkpatrick, 2004) measures attachment towards parents, separately for mother and father. It contains four (in the original version three) paragraphs describing the individual attachment styles: Secure, Insecure/Avoidant, Insecure/Ambivalent, Insecure/Disorganized. Persons with secure attachment describe their parents as generally loving and un- derstanding. Insecure/Avoidant attachment means that parents were generally fine but not very affectionate, and they taught the respondent to be independent and self-sufficient. Insecure/Ambivalent attachment is identified when parents were generally loving but not as understanding as the respondent would have liked. They did not always show love in the best way. Insecure/Disorganized means that parents were generally unpredictable and sometimes even hurtful. 
The respondent is asked to choose the paragraph best fitting to his or her mother and father and subsequently to rate each paragraph on a seven-point scale provided, in the sense of how well every type describes their situation. In our analysis, we used these ratings of every type in correlation analysis.

Relationship Questionnaire (Bartholomew, Horowitz, 1991) measures attachment in current relationships. It contains four paragraphs describing the prototype of the following attachment styles: Secure, Preoccupied, Fearful, Dismissing. Secure people can easily get emotionally close to others and they do not worry about being alone or not accepted by others. Preoccupied people want emotionally close relationships, but they find it difficult to trust others completely, or to depend on them. Fearful people want to be completely emotion- ally intimate with others, but they often find that others are reluctant to get as close as they would like. Dismissing people are characterized as avoiding intimacy, being highly self-reliant and independent. Participants are asked to rate their degree of correspondence to each prototype on a 7-point scale. Again, ratings were used in correlation analysis.

\section{RESULTS}

To analyze the relationships between the dimensions of the conversion process and attachment styles, we performed Pearson correlation analysis. Table 2 presents correlations between conversion dimensions and attachment styles towards the father as measured by the Attachment History Paragraphs. Secure attachment to the father is significantly positively related to parents being a

Table 2. Correlations between attachment styles towards the father and religious conversion process dimensions

\begin{tabular}{|l|c|c|c|c|}
\hline \multirow{2}{*}{ Conversion dimension } & \multicolumn{4}{|c|}{ Attachment History Paragraphs - Father } \\
\cline { 2 - 5 } & Secure & Avoidant & Ambivalent & Disorganized \\
\hline Positive emotions & -0.018 & $0.355^{* *}$ & 0.205 & -0.057 \\
\hline Social influence & -0.142 & 0.083 & $0.283^{* *}$ & 0.023 \\
\hline Relief & -0.070 & $0.255^{*}$ & $0.283^{* *}$ & -0.032 \\
\hline Meaning-searching & -0.070 & -0.048 & 0.040 & 0.142 \\
\hline Feelings of sin & -0.055 & $0.233^{*}$ & 0.183 & -0.036 \\
\hline Parents positive & $0.585^{* *}$ & 0.096 & -0.051 & $-0.576^{* *}$ \\
\hline Religious education & $0.360^{* *}$ & 0.238 & 0.085 & $-0.430^{* *}$ \\
\hline Long-termed conversion & 0.091 & -0.011 & -0.080 & -0.118 \\
\hline Parents compensation & $-0.322^{* *}$ & 0.197 & $0.324^{* *}$ & $0.430^{* *}$ \\
\hline Internal process & 0.009 & -0.057 & -0.021 & -0.018 \\
\hline Crisis before & -0.148 & 0.128 & 0.184 & 0.176 \\
\hline Negative emotions & -0.181 & -0.046 & 0.071 & 0.208 \\
\hline No religiosity before & $-0.245^{*}$ & -0.185 & -0.141 & $0.249^{*}$ \\
\hline Sudden and mystical & -0.188 & 0.190 & $0.226^{*}$ & $0.251^{*}$ \\
\hline
\end{tabular}

$* \mathrm{p} \leq 0.05,{ }^{* *} \mathrm{p} \leq 0.01$ 
positive factor in conversion and religious education, and negatively with parent compensation and no religiosity present before conversion. Avoidant attachment to the father shows significant positive correlations with positive emotions during conversion, relief and feelings of sin. Ambivalent attachment is significantly related to social influence, relief, parent compensation as well as to sudden and mystical conversion. Disorganized attachment to the father correlates significantly with parents being positive factors and religious education (both negatively) as well as with parent compensation, no religiosity present before conversion and sudden and mystical conversion.

Concerning attachment to the mother (Table 3 ), secure attachment is significantly positively related to parents being positive factors in conversion, and negatively with parent compensation and presence of negative emotions during conversion. Avoidant attachment to the mother shows two significant positive correlations, namely with longtermed conversion and parent compensation. Ambivalent attachment to the mother shows no significant correlations and disorganized attachment correlates negatively with parents being a positive factor in conversion.

Table 4 shows correlations between conversion dimensions and attachment in current relationships as measured by the Relationship Questionnaire. As seen, there is no significant correlation. Some of the correlations are of marginal significance, e.g., negative correlation between secure attachment and presence of negative emotions or negative correlation between preoccupied attachment and parents being positive factors in conversion.

Table 3. Correlations between attachment styles towards the mother and religious conversion process dimensions

\begin{tabular}{|l|c|c|c|c|}
\hline \multirow{2}{*}{ Conversion dimension } & \multicolumn{4}{|c|}{ Attachment History Paragraphs - Mother } \\
\cline { 2 - 5 } & Secure & Avoidant & Ambivalent & Disorganized \\
\hline Positive emotions & 0.099 & 0.036 & 0.036 & -0.175 \\
\hline Social influence & -0.019 & -0.083 & -0.083 & -0.013 \\
\hline Relief & -0.039 & 0.040 & 0.093 & -0.074 \\
\hline Meaning-searching & -0.138 & -0.014 & 0.180 & -0.002 \\
\hline Feelings of sin & -0.057 & 0.038 & -0.024 & 0.009 \\
\hline Parents positive & $0.427^{* *}$ & -0.090 & -0.113 & $-0.436^{* *}$ \\
\hline Religious education & $0.286^{* *}$ & -0.007 & -0.042 & -0.153 \\
\hline Long-termed conversion & -0.069 & $0.306^{* *}$ & 0.030 & 0.146 \\
\hline Parents compensation & $-0.370^{* *}$ & $0.286^{* *}$ & 0.170 & $0.413^{* *}$ \\
\hline Internal process & -0.072 & -0.083 & -0.007 & 0.012 \\
\hline Crisis before & 0.002 & 0.001 & 0.059 & 0.026 \\
\hline Negative emotions & $-0.263^{*}$ & 0.010 & 0.082 & 0.223 \\
\hline No religiosity before & -0.193 & 0.086 & 0.167 & -0.140 \\
\hline Sudden and mystical & -0.101 & -0.101 & 0.026 & 0.023 \\
\hline
\end{tabular}

$* \mathrm{p} \leq 0.05, * * \mathrm{p} \leq 0.01$ 
Table 4. Correlations between attachment styles in current relationships and religious conversion process dimensions

\begin{tabular}{|l|c|c|c|c|}
\hline \multirow{2}{*}{ Conversion dimension } & \multicolumn{4}{|c|}{ Relationship Questionnaire } \\
\cline { 2 - 5 } & Secure & Fearful & Preoccupied & Dismissing \\
\hline Positive emotions & 0.027 & 0.113 & 0.126 & -0.014 \\
\hline Social influence & 0.035 & -0.053 & -0.021 & -0.153 \\
\hline Relief & 0.130 & -0.183 & -0.004 & -0.035 \\
\hline Meaning-searching & 0.143 & -0.193 & -0.058 & -0.006 \\
\hline Feelings of sin & -0.093 & -0.078 & 0.188 & 0.106 \\
\hline Parents positive & 0.161 & -0.032 & -0.196 & -0.057 \\
\hline Religious education & 0.010 & -0.063 & 0.107 & 0.080 \\
\hline Long-termed conversion & -0.149 & 0.089 & 0.084 & 0.121 \\
\hline Parents compensation & -0.037 & 0.073 & 0.195 & -0.095 \\
\hline Internal process & 0.000 & 0.128 & 0.076 & 0.176 \\
\hline Crisis before & 0.025 & -0.012 & 0.037 & 0.112 \\
\hline Negative emotions & -0.204 & -0.140 & 0.157 & 0.061 \\
\hline No religiosity before & 0.084 & 0.150 & -0.022 & 0.125 \\
\hline Sudden and mystical & 0.054 & -0.021 & 0.015 & -0.073 \\
\hline
\end{tabular}

$* \mathrm{p} \leq 0.05, * * \mathrm{p} \leq 0.01$

\section{DISCUSSION}

We begin the analysis of our results with the correlations of secure attachment and conversion dimensions. Attachment to the father and mother correlated positively with presence of religious education before conversion as well as parents being positive factors in conversion. Both these variables represent the idea of socialized correspondence hypothesis as described by Granqvist and Hagekull (1999). They argue that if a person possesses internal working models representing secure attachment, religion development reflects partial adoption of sensitive caregiver's religion. This means, that securely attached offsprings are wellsocialized with respect to parental standards, which include religious as well as non-religious values (Granqvist, Kirkpatrick,
2004). This is supported also by negative correlations with dimension parents compensation suggesting that conversion is a compensation for insufficient parents (both in mother and father attachment), and with non-presence of religious education in the convert's history (mother attachment). Description of socialized correspondence hypothesis also suggests that such conversion process is less emotional in comparison to compensation conversion (Granqvist, Kirkpatrick, 2004). This is supported by negative correlation of secure attachment to the mother with negative emotions present during conversion, which suggests that conversion of securely attached people is less stormy and accompanied by stressful feelings. Granqvist (2010) argues that such religiosity is not primarily based on distress regulation as it is in insecurely attached people. 
Our results show support also for the compensation hypothesis. Both avoidant and ambivalent attachments to the father correlate positively with the dimension 'relief', which describes the fact that conversion led to solving some problems or to the alleviation from problems. This represents support for the distress regulation assumption, which says that distress regulation is at the core of religion as compensation (Granqvist, 2010). In our case, religious conversion was used as a tool for coping with different problems (see also Pargament, 1996). Avoidant attachment to the father also correlated positively with positive emotion during conversion, feelings of sin, and ambivalent attachment to the father is positively correlated with social influence, parents compensation and conversion being sudden and mystical. Pattern of these correlations points very clearly to the assumption related to compensation hypothesis, which says that compensation religiosity is more emotionally based and God is used primarily for regulating distress (Granqvist, Hagekull, 1999; Granqvist, Kirkpatrick, 2004), in our case, feelings of sin or other emotional or non-emotional problems. Positive correlation with positive feelings and relief suggests that this process is frequently successful and leads to alleviation in which God is used as a source of safety. However, we did not fully confirm the assumption about sudden conversion of people with insecure attachment (Granqvist, Kirkpatrick, 2004), as only ambivalent and disorganized attachment to the father correlated with this dimension, and avoidant attachment to the mother correlated positively with long-termed conversion.

Very special case is the disorganized attachment. It had strong correlations with parents dimensions of the conversion pro- cess (negative with parents positive and positive with parents compensation, both in the mother and father), the highest from all insecure attachments. Other significant correlations include negative correlation of this attachment type with religious education and positive with no religiosity on the part of the father. Also, disorganized attachment to the father correlated positively with sudden and mystical conversion. The inclination of a person attached in a disorganized way to mystical experiences was described by Granqvist et al. (2012). They argue that these experiences should not be viewed as an expression of absorption/dissociation and its linkage to attachment disorganization cannot be taken as a dismissal or metaphysical interpretation of those experiences. Rather, it should be understood as a developmental precursor of mystical experiences, and this connection is based primarily on the associations between disorganized attachment and the propensity to enter altered states of consciousness on one hand and between absorption and mystical experiences on the other.

Our results showed also considerable differences between parental attachment and attachment in current relationships. Parental attachment showed several significant correlations with conversion dimensions, however, attachment in current relationships displays no significant relationship with any dimension of the conversion process. It should be said that almost all previous results relating to attachment and conversion included the study of parental attachment (Kirkpatrick, 1997, 1998; Granqvist, Kirkpatrick, 2004; Schnitker et al., 2012) and not attachment in a current relationship. Although some research suggests that there exists some relationship between parental 
and adult attachment (Davila, Cobb, 2004), our results do not confirm the possible assumption that they share the same effect on the other variables. In this case, parental attachment is a stronger factor in predicting the conversion process. It could be said that parental figures and their images in the internal working models, and not partners or friends are the sources of the way how God is used for emotion regulation.

Another point to discuss is the difference between attachment to the father and mother. As we mentioned above, previous results attributed a greater influence on the conversion to the father, as the father was more frequently perceived as problematic in the group of converts in comparison to the mother (Ullman, 1982, 1989; Buchbinder et al., 1997). Our results provide partial support for this finding, as correlations of attachment to the father were somewhat higher and more frequent than correlations to the mother. Explanation for this finding could be based on the image of God in the Catholic religion, which was the religion of our sample. God in this religion is described and understood more in a male way, and very frequently presented as a father. However, the results supporting the father role are not extensive (in correlation size) and there are some inconsistencies in these results, e.g., significant correlations of attachment to the mother which are not present in the attachment to the father. It suggests that both the father and the mother figure can have an impact on conversion and should be taken into account when considering this topic.

\section{CONCLUSION}

To conclude, our results confirmed that parental attachment is related to dimensions of religious conversion. The patterns of correlation give support to the compensation hypothesis, suggesting that individuals with insecure attachment establish compensatory attachment relationships with God to regulate emotional distress and they experience sudden and more emotionally driven conversion. The socialized correspondence hypothesis, which assumes that persons with secure attachment develop religion through adoption of caregiver's standards, was also supported. A support was shown for the bigger influence of the father than mother on conversion, but this support was only partial. All these results confirmed that attachment provides proper framework for studying religious phenomena and can be used as an approach for research in this area.

Received February 26, 2013

\section{REFERENCES}

ADAMOVOVÁ, L., HALAMA, P., 2009, Vzt'ahová väzba a religiozita. Bratislava: Slovak Academic Press.

AINSWORTH, M.D.S., BLEHAR, M.C., WATERS, E., WALL, S., 1978, Patterns of attachment. Hillsdale: Lawrence Erlbaum Associates.

BARTHOLOMEW, K., HOROWITZ, L.M., 1991, Attachment style among young adults: A test of a four-category model. Journal of Personality and Social Psychology, 61, 226-244.

BOWLBY, J., 1969, Attachment and loss. Vol. 1 Attachment. London: Pimlico.

BOWLBY, J., 1973, Attachment and loss. Vol 2 Separation. London: Penguin.

BUCHBINDER, J.T., BILU, Y., WITZTUM, E., 1997, Ethnic background and antecedent of religious conversion among Israeli Jewish outpatients. Psychological Reports, 81, 1187-1202.

BUXANT, C., SAROGLOU, V., CASALFIORE, S., CHRISTIANS, L., 2007, Cognitive and emotional characteristics of New Religious Movement members: New questions and data on the mental health issues. Mental Health, Religion, \& Culture, $10,219-238$. 
COBB, R., DAVILA, J., BRADBURY, T., 2001, Attachment security and marital satisfaction: The role of positive perceptions and social support. Personality and Social Psychology Bulletin, 27, 1131-1143

DAVILA, J., COBB, R.J., 2004, Predictors of changes in attachment security during adulthood. In: W.S. Rholes, J.A. Simpson (Eds.), Adult attachment: Theory, research, and clinical implications, (pp. 133-156). New York: Guilford Press.

FEENEY, J.A., 1999, Adult romantic attachment and couple relationships. In: J. Cassidy, P.R. Shaver (Eds.), Handbook of attachment: Theory, research, and clinical applications (pp. 355-377). New York: Guilford Press.

GRANQVIST, P., 1998, Religiousness and perceived childhood attachment: On the question of compensation or correspondence. Journal for Scientific Study of Religion, 37, 350-367.

GRANQVIST, P., 2003, Attachment theory and religious conversions: A review and a resolution of the classic and contemporary paradigm chase. Review of Religious Research, 45, 172-187.

GRANQVIST, P., 2010, Religion as attachment: The Godin Award Lecture. Archive for the Psychology of Religion, 32, 5-24.

GRANQVIST, P., HAGEKULL, B., 1999, Religiousness and perceived childhood attachment: Profiling socialized correspondence and emotional compensation. Journal for the Scientific Study of Religion, 38, 254-273.

GRANQVIST, P., HAGEKULL, B., IVARSSON, T., 2012, Disorganized attachment promotes mystical experiences via a propensity for alterations in consciousness (Absorption). The International Journal for the Psychology of Religion, 22, 180-197.

GRANQVIST, P., KIRKPATRICK, L.A., 2004 Religious conversion and perceived childhood attachment: A metaanalysis. International Journal for the Psychology of Religion, 14, 223-250.

HALAMA, P., 2005, Religious Conversion Process Questionnaire - unpublished manual. [in Slovak]

HAZAN, C., SHAVER, P.R., 1990, Love and work: An attachment theoretical perspective. Journal of Personality and Social Psychology, 59, 270-280.

KIRKPATRICK, L.A., 1997, A longitudinal study of changes in religious belief and behaviour as a function of individual differences in adult attachment style. Journal for the Scientific Study of Religion, 36, 207-217.

KIRKPATRICK, L.A., 1998, God as a substitute attachment figure: A longitudinal study of adult at- tachment style and religious change in college students. Personality and Social Psychology Bulletin, 24, 961-973.

KIRKPATRICK, L.A., 2005, Attachment, evolution and the psychology of religion. New York: Guilford Press.

KIRKPATRICK, L.A., SHAVER, P.R., 1990, Attachment theory and religion: Childhood attachments, religious beliefs and conversion. Journal for the Scientific Study of Religion, 29, 315-334.

LIMKE, A., MAYFIELD, P.B., 2011, Attachment to God: Differentiating the contributions of fathers and mothers using the Experiences in $\mathrm{Pa}$ rental Relationships Scale. Journal of Psychology and Theology, 39, 2, 122-129.

MAIN, M., CASSIDY, J., 1988, Categories of response to reunion with the parent at age 6: Predictable from infant attachment classifications and stable over a 1-month period. Developmental Psychology, 24, 415-426.

MAIN, M., SOLOMON, J., 1990, Procedures for identifying infants as disorganized/disoriented during the Ainsworth Strange Situation. In: M.T. Greenberg, D. Cicchetti, E.M. Cummings (Eds.), Attachment in the preschool years (pp. 121-160). Chicago: University of Chicago Press.

MCDONALD, A., BECK, R., ALLISON, S., NORSWORTHY, L., 2005, Attachment to God and parents: Testing the correspondence vs. compensation hypotheses. Journal of Psychology and Christianity, 24, 1, 21-28.

MENDONCA, D., OAKES, K.E., CIARROCCHI, J.W., SNECK, W.J., GILLESPIE, K., 2007, Spirituality and God-attachment as predictors of subjective well-being for seminarians and nuns in India. Research in the Social Scientific Study of Religion, 18, 121-140.

MIKULINCER, M., SHAVER, P.R., 2007, Attachment in adulthood: Structure, dynamics, and change. New York: Guilford Press.

MINER, M., 2009, The impact of child-parent attachment, attachment to God and religious orientation on psychological adjustment. Journal of Psychology and Theology, 37, 2, 114-124.

MURKEN, S., NAMINI, S., 2007, Childhood familial experiences as antecedents of adult membership in new religious movements. A literature review. Nova Religio: The Journal of Alternative and Emergent Religions, 10, 4, 17-37.

PARGAMENT, K.I., 1997, The psychology of religion and coping. New York: The Guilford Press. PIETROMONACO, P.R., GREENWOOD, D., FELDMAN BARRETT, L., 2004, Conflict in adult 
close relationships: An attachment perspective. In: W.S. Rholes, J.A. Simpson (Eds.), Adult attachment: New directions and emerging issues (pp. 267-299). New York: Guilford Press.

REINER, S.R., ANDERSON, T.L., LEWIS HALL, M.E., HALL, T.W., 2010, Adult attachment, God attachment and gender in relation to perceived stress. Journal of Psychology and Theology, 38, 3, 175-185.

SCHNITKERA, S.A., PORTERB, T.J., EMMONS, R.A., BARRETTA, J.L., 2012, Attach- ment predicts adolescent conversions at Young Life Religious Summer Camps. International Journal for the Psychology of Religion, 22, 3, 198215.

ULLMAN, C., 1982, Cognitive and emotional antecedents of religious conversion. Journal of Personality and Social Psychology, 43, 1, 183192.

ULLMAN, C., 1989, The transformed self. The psychology of religious conversion. New York: Plenum Press.

\title{
VZŤAHMEDZI ŠTÝLMI VZŤAHOVEJVÄZBYA DIMENZIAMI PROCESUNÁBOŽENSKEJ KONVERZIE
}

\author{
P. H a 1 a m a, M. G a š p a rí k o vá, M. S a b o
}

Súhrn: Štúdia je založená na predpoklade, že systém vztahovej väzby je tesne zviazaný z religiozitou a religióznym správaním. Predchádzajúci výskum ukázal, že typ vzt'ahovej väzby súvisí s náboženskou konverziou. Neistá vzt'ahová väzba súvisela s náhlou a emocionálnou konverziou a bezpečná vzt'ahová väzby súvisela s postupnou adaptáciou náboženstva opatrovatel'a. Tento výskum sa podrobnejšie zameriava na vztah medzi štýlmi vzt’ahovej väzby a procesom náboženskej konverzie. 101 príslušníkov krest’anského náboženstva vyplnilo Dotazník procesu náboženskej konverzie merajúci rôzne aspekty priebehu náboženskej konverzie a dva dotazníky vzt’ahovej väzby: História vzt'ahovej väzby na meranie vzt’ahovej väzby voči rodičom, a Dotazník vzt'ahu, ktorý meria vzt’ahovú väzbu v aktuálnych vzt’ahoch. Korelačná analýza medzi dimenziami konverzie a vzt’ahovou väzbou ukázala, že bezpečná vzt’ahová väzba voči rodičom súvisela $\mathrm{s}$ prítomnost'ou istého náboženského vzdelanie pred konverziou a rodičmi ako pozitívnym faktorom pri konverzii. Na druhej strane, neistá vzt’ahová väzba voči rodičom (najmä voči otcovi) korelovala s prežívaním konverzie ako viac náhleho, emóciami hnaného procesu sprevádzaného mystickými zážitkami. Tieto výsledky podporujú kompenzačnú aj socializačnú hypotézu ako sú opísané v teórii a výskume týkajúcom sa vzt’ahovej väzby a religiozity. 